\title{
Centripetal Forces in China's Economic Takeoff
}

\author{
ANURADHA DAYAL-GULATI and AASIM M. HUSAIN*
}

This paper uses provincial time series data from the People's Republic of China to empirically investigate two propositions relating to economic development: (i) that economic takeoff-or an acceleration in economic growth-is associated with inflows of foreign direct investment (FDI), possibly through technological transfer; and (ii) that takeoff is accompanied, at least in the short term, by widening income inequality. The results indicate that FDI flows have increased the rate of convergence in per capita incomes across China's provinces. However, the pattern of FDI, which has gone mainly to the relatively wealthy provinces, has caused different provinces to converge toward different steady states. [JEL O4, O11, O18]

E conomic takeoff is often associated with technological transfer from other countries, largely through foreign direct investment (FDI). Also, economic development is often linked with rising inequality, at least in the short term. The logic tying these two ideas together is straightforward-relatively prosperous countries or regions tend to receive more FDI because they have the existing infrastructure to support such projects. Hence, inequality across countries or regions widens as a result of FDI, which in turn helps achieve economic takeoff.

\footnotetext{
* Anuradha Dayal-Gulati is a Clinical Associate Professor at the Kellogg Graduate School of Management, Northwestern University, and Aasim M. Husain is Assistant to the Director in the Research Department of the International Monetary Fund. The majority of this work was completed when Anuradha Dayal-Gulati was an Economist in the IMF Institute and Aasim Husain was a Senior Economist in the Asia and Pacific Department of the IMF. We would like to thank, without implicating, Jahangir Aziz, Tamim Bayoumi, Paul Cashin, Mohsin Khan, Peter Montiel, Ichiro Otani, David Robinson, Reza Vaez-Zadeh, and an anonymous referee for helpful comments on earlier drafts of this paper. We are also indebted to Kirsten Fitchett, Lakshmi Sahasranam, Bin Zhang, and Rui Zhao for their help with assembling the data.
} 
Cross-country empirical analysis of these propositions, however, is complicated by institutional and policy differences across countries, which can render comparisons problematic. As such caveats do not apply across regions of the same country, provincial-level data from China over the past two decades can be used to provide interesting empirical insight into these propositions relating to the process of economic development. ${ }^{1,2}$

China's growth performance since the initiation of market-oriented reform in 1978 has been impressive. Real GDP has grown by an average annual rate of almost 10 percent; real per capita output has averaged $81 / 4$ percent a year. This economic takeoff has coincided with large inflows of FDI, which have averaged over US $\$ 40$ billion (51/2 percent of GDP) annually in recent years. At the same time, however, the variation in economic performance across provinces has widened, particularly since the late 1980s. After declining in the late 1970s and 1980s, the dispersion of (the natural logarithm of) provincial per capita incomes increased steadily in the 1990s (Figure 1). ${ }^{3}$ In 1978, real per capita income in the richest province was around six times that of the poorest; by 1997, the multiple had risen to almost eight (Table 1). Similarly, the pattern of FDI across provinces and regions has differed sharply. The coastal region, for example, saw FDI inflows averaging over 9 percent of regional GDP during 1993-97, while FDI in the western and southeastern regions averaged only $1-2$ percent over the same period.

The apparent widening disparity across China's provinces-or groups of provinces - raises the question of whether provincial per capita incomes have diverged and, if so, why? This paper investigates the variation in economic performance across provinces and empirically examines whether the poorer provinces grew faster than the richer ones, which would suggest that all the provinces were converging to the same steady-state real per capita income level. ${ }^{4}$ In addition, the paper investigates the role of FDI and other structural and policy factorsincluding the share of investment in provincial GDP, the dominance of stateowned enterprises (SOEs) in industrial output, and the role of the banking system-on economic growth over the period 1978-97.

The analysis presented in this paper indicates that absolute convergenceconvergence of real per capita incomes in all provinces to the same steady-state level-does not appear to hold over the past two decades, although there appears to be evidence of conditional convergence-that is, convergence of provincial per capita incomes to their own steady states. While structural characteristics of the provincial economies - such as the share of investment to GDP and the share of

\footnotetext{
${ }^{1}$ All references to China in this paper are to the People's Republic of China.

${ }^{2}$ Strictly speaking, propositions in the literature regarding rising Kuznets-type income inequality generally relate to widening disparity across income groups within a given country or region (see, for example, Ben-David, 1993), while the analysis reported below refers to inequality of income growth rates across provinces or regions within China. Clearly, widening disparity of one type need not necessarily be associated with greater inequality in the other sense.

${ }^{3}$ The coefficient of variation - the standard deviation divided by the mean —of real per capita incomes (also depicted in Figure 1) shows a similar pattern.

${ }^{4}$ As noted by Cashin and Sahay (1996), convergence of per capita incomes is a necessary, but not sufficient, condition for a reduction in the dispersion of per capita incomes.
} 
Figure 1. Provinces' Real Per Capita Incomes, 1978-97

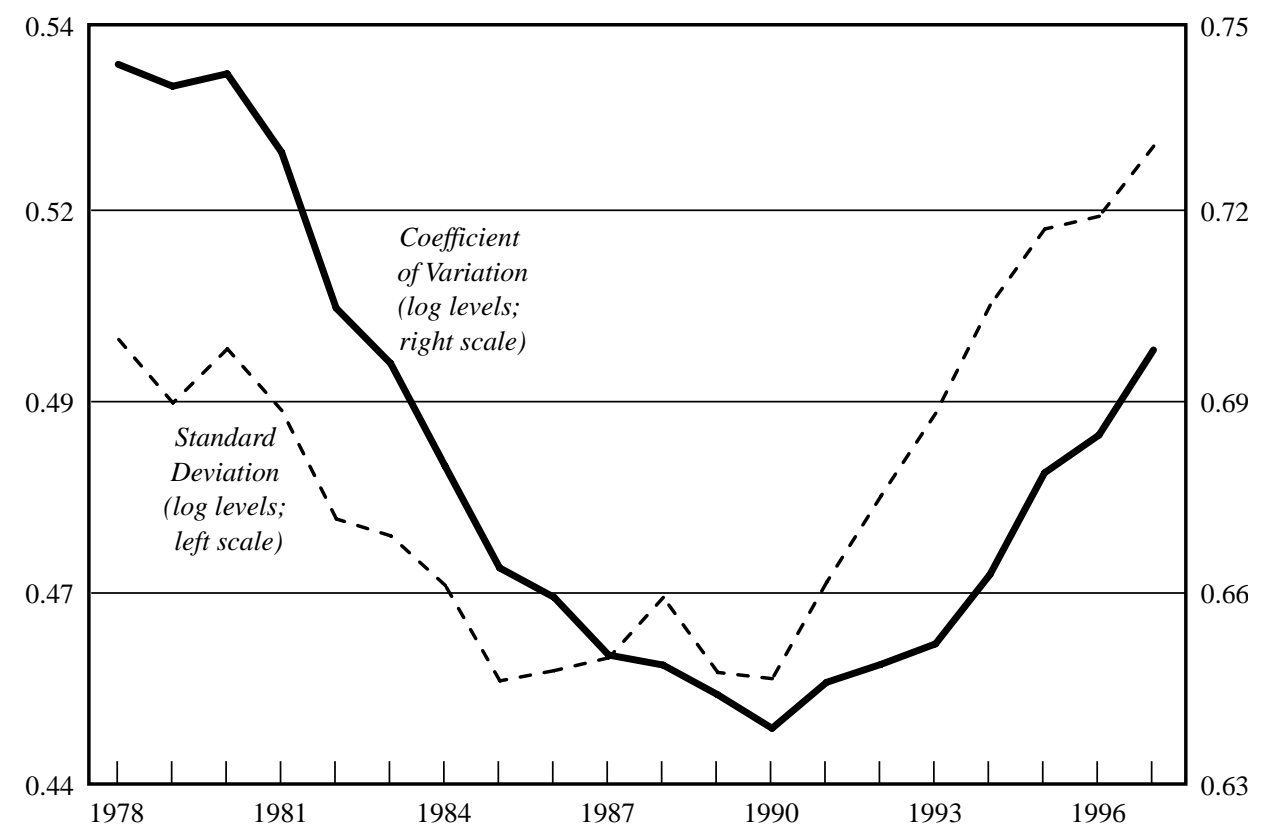

SOEs in industrial output — have had some effect, the regional disparities appear to be influenced primarily by the relative importance of FDI to the region. Indeed, the inclusion of an FDI variable in the regressions results in a sizable increase in the estimated rate of convergence of each region to its own steady state.

\section{Absolute and Conditional Convergence}

There is a growing literature on convergence of per capita incomes across and within countries. If economies possess similar levels of technology and have similar preferences, then the neoclassical growth model predicts that all provinces would converge to similar levels of real per capita income in the steady state. This is known as absolute $\beta$ convergence. Convergence of per capita incomes in this model is driven by the assumption of diminishing returns to capital. When the stock of capital is low, each addition to capital stock generates large increases in output. These increments tend to decrease as the stock of capital increases. Accordingly, if the only difference between economies is the initial level of capital stock, the neoclassical growth model predicts that poorer economies will grow faster than rich ones. Regions with lower starting capital-labor ratios will have higher per capita growth rates.

The empirical evidence suggests that convergence is absolute within homogeneous groups of economies. Barro and Sala-i-Martin (1991, 1992a, 1992b) examine data for the U.S. states from 1880-1990, for Japanese prefectures over 


\begin{tabular}{|c|c|c|c|c|c|c|}
\hline & \multicolumn{3}{|c|}{ In 1992 Yuan } & \multicolumn{3}{|c|}{ In Percent of 1978 National Average } \\
\hline & 1978 & 1988 & 1997 & 1978 & 1988 & 1997 \\
\hline North & 947 & 2,002 & 4,411 & 120 & 253 & 558 \\
\hline Beijing & 2,435 & 5,302 & 11,229 & 308 & 670 & 1,420 \\
\hline Tianjin & 2,003 & 3,895 & 8,626 & 253 & 492 & 1,091 \\
\hline Hebei & 746 & 1,543 & 3,867 & 94 & 195 & 489 \\
\hline Shanxi & 772 & 1,564 & 3,051 & 98 & 198 & 386 \\
\hline Inner Mongolia & 630 & 1,525 & 2,967 & 80 & 193 & 375 \\
\hline Northeast & 1,202 & 2,488 & 4,650 & 152 & 314 & 588 \\
\hline Liaoning & 1,436 & 3,081 & 5,823 & 182 & 390 & 736 \\
\hline Jilin & 782 & 1,968 & 3,726 & 99 & 249 & 471 \\
\hline Heilongjiang & 1,238 & 2,180 & 4,015 & 157 & 276 & 508 \\
\hline Coastal & 859 & 2,358 & 6,376 & 109 & 298 & 806 \\
\hline Shanghai & 3,499 & 6,763 & 16,297 & 442 & 855 & 2,060 \\
\hline Jiangsu & 772 & 2,192 & 6,046 & 98 & 277 & 764 \\
\hline Zhejiang & 689 & 2,267 & 6,622 & 87 & 287 & 837 \\
\hline Fujian & 636 & 1,735 & 5,635 & 80 & 219 & 712 \\
\hline Guangdong & 795 & 2,684 & 6,700 & 101 & 339 & 847 \\
\hline Shandong & 736 & 1,870 & 5,059 & 93 & 236 & 640 \\
\hline Hainan & $\ldots$ & 1,552 & 4,132 & $\ldots$ & 196 & 522 \\
\hline Southeast & 560 & 1,275 & 2,858 & 71 & 161 & 361 \\
\hline Anhui & 511 & 1,201 & 2,832 & 65 & 152 & 358 \\
\hline Jiangxi & 509 & 1,112 & 2,611 & 64 & 141 & 330 \\
\hline Henan & 477 & 1,173 & 2,644 & 60 & 148 & 334 \\
\hline Hubei & 666 & 1,598 & 3,592 & 84 & 202 & 454 \\
\hline Hunan & 655 & 1,306 & 2,679 & 83 & 165 & 339 \\
\hline South & 443 & 947 & 1,974 & 56 & 120 & 250 \\
\hline Guangxi & 625 & 1,075 & 2,723 & 79 & 136 & 344 \\
\hline Sichuan & 516 & 1,181 & 2,443 & 65 & 149 & 309 \\
\hline Guizhou & 376 & 851 & 1,458 & 48 & 108 & 184 \\
\hline Yunnan & 561 & 1,277 & 2,522 & 71 & 161 & 319 \\
\hline West & 622 & 1,408 & 2,557 & 79 & 178 & 323 \\
\hline Tibet & $\ldots$ & 1,246 & 2,571 & $\ldots$ & 158 & 325 \\
\hline Shaanxi & 550 & 1,370 & 2,356 & 70 & 173 & 298 \\
\hline Gansu & 566 & 1,115 & 2,089 & 72 & 141 & 264 \\
\hline Qinghai & 1,010 & 1,700 & 2,670 & 128 & 215 & 338 \\
\hline Ningxia & 722 & 1,487 & 2,618 & 91 & 188 & 331 \\
\hline Xinjiang & 726 & 1,837 & 3,562 & 92 & 232 & 450 \\
\hline China & 791 & 1,788 & 3,586 & 100 & 226 & 453 \\
\hline
\end{tabular}


the period 1930-90, and for the regions of eight European countries from 1950-90. They find that convergence is absolute in that it applies when no other variable other than the initial level of per capita income is held constant. Cashin and Sahay (1996) examine convergence within India and find that variations in the steady state values across states are not significant, implying absolute convergence.

If economies vary in their saving rates and technologies, then the neoclassical growth model predicts conditional $\beta$ convergence-provincial per capita incomes still converge, but this convergence is conditional on each economy's own steady state. Across countries, the accumulated empirical evidence suggests that convergence is conditional-after taking into account the effects of the rate of investment and public policies on per capita growth. ${ }^{5}$ In most cases, the empirical work does not provide robust estimates for the effects of a specific government policy on growth, but it shows that the overall package of policies matters a great deal. The tendency towards convergence is even stronger when a measure of human capital in the form of educational attainment and health is included as an explanatory variable. 6

Thus, if all the provinces of China have similar levels of technology and similar preferences, then they would converge to the same level of per capita income in the steady state (absolute convergence). If, on the other hand, provinces' technologies vary - possibly on account of their ability to attract FDI - they would not be expected to converge to the same steady state, at least as long as their attractiveness to FDI remained varied. ${ }^{7}$

Capital and labor mobility - or openness - affect the rate of convergence. For example, the availability of foreign finance makes it easier to acquire physical capital. With the associated increase in the capital stock, diminishing returns set in faster than they would in a closed economy. Hence, the speed of convergence is greater in open economies than in closed ones. ${ }^{8}$

The evidence from China suggests that mobility of labor and capital across provinces in China has been limited by policies. ${ }^{9}$ For instance, permission for households to move from rural to urban areas has been restricted, and capital

\footnotetext{
5Public policies include the volume of consumption spending and the associated level of taxation, some form of public investment, and institutional infrastructure.

${ }^{6}$ See Barro and Sala-i-Martin (1995) for a review of this literature.

${ }^{7}$ The creation of special economic zones in some of the coastal provinces may have facilitated the inflow of FDI. To that extent, greater inflows of FDI could be associated with higher capital mobility, thereby raising the rate of convergence. Nevertheless, other factors, such as proximity to Hong Kong SAR and Taiwan Province of China-where much of the FDI originated - and their relatively richer human capital endowment were likely also important factors explaining the coastal provinces' ability to attract FDI. Such differential ability to attract FDI, rather than access to FDI, would explain provinces' convergences to different steady states, as suggested by our results.

${ }^{8}$ Labor mobility is analogous to capital mobility and also tends to speed up an economy's convergence towards its steady state position. While the empirical evidence for convergence in the regional data after taking into account net migration is not definitive, Cashin and Sahay (1996) find that migration is an especially slow means of equalizing per capita incomes.

${ }^{9}$ Appendix II provides some background information on policies relating to capital and labor mobility.
} 
mobility has also been dampened through tax policies and state control over bank lending. Therefore, with partial capital and labor mobility, output convergence across provinces is likely to be more gradual. However, policies have also sought to directly redistribute incomes from relatively rich regions to poorer provinces, thereby boosting the rate of convergence. Thus, a relevant question for China is whether policies have, in total, contributed to the equalization of provincial per capita incomes.

Previous empirical studies of provincial economic performance and convergence in China include Bell, Khor, and Kochhar (1993) and Zhao (1998). Bell, Khor, and Kochhar, using the real annual average provincial growth rate during 1981-90, find that poorer provinces tended to grow faster than richer ones. This finding appears to depend critically on the sample period, however, during much of which there was a rapid expansion in agricultural output following the liberalization of the agricultural sector. Indeed, as Figure 1 indicates, the dispersion of provincial per capita incomes narrowed considerably during this period, before increasing steadily in the 1990s. Bell, Khor, and Kochhar also find that the proportion of nonstate sector output in total output was positively related to growth, while there was not a statistically significant relationship in their growth regression between FDI and growth. ${ }^{10}$ Zhao observes that the evolution of the ratio of real per capita GDP in the richest province to that in the poorest province was Ushaped, and empirically investigates the role of capital mobility in explaining this trend. She finds that capital mobility across China's provinces was relatively limited during the 1980s and 1990s (see Appendix II).

Very recent work using our dataset by Graham and Wada (2001) and Aziz and Duenwald (2001) generally supports and extends our findings. Graham and Wada empirically assess whether inflows of FDI may have been associated with an acceleration in total factor productivity (TFP) growth, possibly resulting from technology transfer embodied in FDI inflows. They conclude that FDI has indeed contributed to growth in the provinces and regions of China-particularly the coastal region-that received sizable flows of this type, beyond what would be expected from higher rates of capital formation enabled by the FDI. Aziz and Duenwald investigate the implications of alternative convergence tests on our results. Using the methodology suggested by Quah (1997) to more fully exploit information contained in the data, they compute kernel estimates of the relative income distribution of China's provinces. Their results - that the distribution of relative incomes is clustering toward two separate relative income clubs, with the coastal provinces (which received the most FDI) gravitating towards a higher per capita income mode than the other provinces-are consistent with our finding of conditional convergence.

In another related recent study, Wei and Wu (2001) empirically assess the relation between openness and rural-urban income inequality in Chinese cities and their adjacent rural areas during 1988-93. Defining openness as the ratio of

\footnotetext{
${ }^{10}$ By regressing average growth on only FDI, however, Bell, Khor, and Kochhar (1993) obtain a significant positive coefficient.
} 
exports to GDP, and allowing for endogeneity by using distance to major seaports as an instrument for openness, they find that while average openness increased and overall rural-urban inequality also went up during this period, the correlation across cities was negative. Together with our results, this would seem to suggest that within-province inequality has improved while interprovincial inequality has worsened. However, such an interpretation is subject to at least two qualifications. First, the Wei and $\mathrm{Wu}$ results are based on a much shorter time period. Indeed, as illustrated in Figure 1, much of the rise in the dispersion of average per capita incomes across provinces took place after the period studied by Wei and $\mathrm{Wu}$. Second, special economic zones, which received a large share of China's total FDI inflows, were excluded from Wei and Wu's sample. The direction in which this exclusion might affect their result is not clear.

\section{Regional Economic Performance}

The basic estimation sample covers 28 provinces and municipalities over the period 1978 to $1997 .{ }^{11}$ The output data used are provincial GDP in constant (1992 yuan) prices based on provincial price deflators. ${ }^{12}$ These estimates are divided by the provincial population estimates to get provincial real GDP per capita, which is used as a proxy for real per capita income. ${ }^{13}$ For analytical purposes, the data are also divided into nonoverlapping intervals of five years each-1978-82, 1983-87, 1988-92, and 1993-97. Using the rate of growth of per capita output over a fiveyear interval rather than a single year provides a simple means of smoothing out short-run cyclical fluctuations in the rate of capacity utilization. This helps ensure that this variable approximates output growth at the average rate of capacity utilization. ${ }^{14}$ Averages of the explanatory variables over the five-year intervals are used in the estimation procedures.

It is convenient for analytical purposes to divide the provinces and municipalities of China into six geographic regions-northern, northeastern, coastal, southeastern, southern, and western. The northern region consists of Hebei, Shanxi, and Inner Mongolia, as well as the municipalities of Beijing and Tianjin. The northeast, which comprises Liaoning, Jilin, and Heilongjiang provinces, has a higher concentration of state-owned industry than the rest of the country. The coastal region-consisting of the municipality of Shanghai

\footnotetext{
${ }^{11}$ Hainan and Tibet Autonomous Region were excluded from the estimations owing to lack of data covering the entire sample period. Data for Chongqing, which became an independent municipality in 1997, are included in the data for Sichuan.

${ }^{12}$ See Appendix I for a description of the variables and data sources.

${ }^{13}$ Time series income data at a macro level are not available. Consequently, per capita incomes and per capita output are used interchangeably in this paper.

${ }^{14}$ Although there is some degree of arbitrariness in assuming that the duration of the business cycle is five years and is synchronized across provinces and the periods chosen, a study by Khan and Kumar (1997) using a similar approach does not find that the results are sensitive to the choice of a three- or fiveyear average. It may also be noted that Husain (1998) finds that cycles were about that long in each region in China, although the cycles tended not to be perfectly synchronized across regions.
} 
and the provinces of Jiangsu, Zhejiang, Fujian, Shandong, Guangdong, and Hainan-has been the recipient of the bulk of foreign direct investment (FDI), particularly from Hong Kong SAR. The southeastern provinces-Anhui, Jiangxi, Henan, Hubei, and Hunan-are adjacent to the coastal region and have received an increasing share of FDI in recent years. The southern region, which includes Guangxi, Sichuan, Guizhou, and Yunnan, is more dependent on the agricultural sector than the other regions. Finally, the western region, comprising Tibet Autonomous Region, Shaanxi, Gansu, Qinghai, Ningxia, and Xinjiang, accounts for around one half of China's land area but only 7 percent of its population. ${ }^{15}$

\section{Growth Performance}

Economic performance, as measured by the growth in real GDP per capita, has varied significantly across regions and over time (Table 2). For China as a whole, real per capita GDP growth averaged 6 percent in the early post-reform period (1978-82), but picked up markedly in 1983-87 following the introduction of market-oriented reforms in the agricultural sector. Per capita income growth slowed during 1988-92, but picked up again in 1993-97 after the launch of a major investment drive in the coastal region.

While the coastal region grew at a faster pace than the rest of the country in each of the four subperiods, the relative performance of the other regions varied. For example, growth in the southeastern region exceeded the national average only in the first and last subperiods, while that in the northern and northeastern regions exceeded the national average only in the last subperiod. As a result, the relative position of the regions in terms of the average level of real per capita GDP has shifted, and each region's share in China's overall GDP has changed (Table 3 ). The share of the coastal region, for example, has risen from around one third in the late 1970 s to over 40 percent in recent years.

The data also indicate a strong positive relation between initial income and the pickup in growth during the post-reform period. As illustrated in Figure 2, the increase in average growth between 1978-82 and 1993-97 was smallest for the initially poorest southern region, and greatest for the initially richest northeastern and northern regions.

${ }^{15}$ While lumping municipalities and provinces is potentially problematic, we chose to maximize the size of the sample by including municipalities for a number of reasons. First, municipalities are independent administrative units, in the same way as provinces, and data for both are collected and compiled in the same fashion. Second, special features of municipalities-such as their relative prosperity and high degree of urbanization — should be captured by variables included in the estimations reported below, such as initial per capita income and agriculture's share of output. Indeed, the municipalities did not stand out as outliers in the regressions, and when provincial dummies were included, coefficient estimates for dummies associated with municipalities were not out of line with those for provinces. Third, the dispersion of provincial per capita incomes exhibits an even stronger increase in the 1990s when municipalities are excluded, suggesting that the convergence to different steady states finding does not rest on the inclusion of municipalities in our sample. 


\begin{tabular}{|c|c|c|c|c|c|}
\hline \multicolumn{6}{|c|}{$\begin{array}{l}\text { Table 2. Regional Per Capita Income Growth Rates } \\
\text { (annual average; in percent) }\end{array}$} \\
\hline & $1978-82$ & $1983-87$ & 1988-92 & 1993-97 & 1978-97 \\
\hline North & 5.2 & 9.6 & 6.7 & 11.7 & 8.4 \\
\hline Beijing & 4.6 & 10.4 & 7.3 & 10.5 & 8.4 \\
\hline Tianjin & 5.3 & 8.7 & 4.7 & 12.9 & 8.0 \\
\hline Hebei & 4.1 & 9.5 & 8.1 & 13.6 & 9.0 \\
\hline Shanxi & 5.6 & 8.9 & 5.5 & 9.6 & 7.5 \\
\hline Inner Mongolia & 8.4 & 10.1 & 6.3 & 9.3 & 8.5 \\
\hline Northeast & 3.9 & 10.2 & 5.6 & 9.3 & 7.4 \\
\hline Liaoning & 2.9 & 12.0 & 5.4 & 9.5 & 7.6 \\
\hline Jilin & 5.1 & 12.5 & 5.6 & 10.7 & 8.6 \\
\hline Heilongjiang & 4.5 & 6.6 & 5.7 & 8.4 & 6.4 \\
\hline Coastal & 8.4 & 11.3 & 9.7 & 14.4 & 11.1 \\
\hline Shanghai & 5.3 & 7.6 & 6.8 & 13.5 & 8.4 \\
\hline Jiangsu & 8.2 & 12.8 & 9.9 & 14.3 & 11.4 \\
\hline Zhejiang & 11.9 & 13.8 & 9.1 & 15.7 & 12.6 \\
\hline Fujian & 10.4 & 10.3 & 10.7 & 17.0 & 12.2 \\
\hline Guangdong & 9.0 & 12.2 & 12.4 & 13.4 & 11.9 \\
\hline Shandong & 7.8 & 11.2 & 8.7 & 14.6 & 10.7 \\
\hline Hainan $^{1}$ & $\ldots$ & 6.6 & 13.7 & 8.7 & 10.4 \\
\hline Southeast & 7.4 & 10.0 & 5.6 & 12.7 & 9.0 \\
\hline Anhui & 7.9 & 10.8 & 3.6 & 15.4 & 9.4 \\
\hline Jiangxi & 7.2 & 8.6 & 7.8 & 12.1 & 9.0 \\
\hline Henan & 7.3 & 11.5 & 5.9 & 12.7 & 9.4 \\
\hline Hubei & 8.8 & 10.1 & 5.7 & 12.6 & 9.3 \\
\hline Hunan & 5.9 & 8.3 & 5.6 & 10.7 & 7.7 \\
\hline South & 6.7 & 9.1 & 6.6 & 10.3 & 8.3 \\
\hline Guangxi & 6.5 & 5.5 & 7.2 & 12.8 & 8.1 \\
\hline Sichuan & 6.6 & 10.6 & 6.4 & 10.3 & 8.5 \\
\hline Guizhou & 7.5 & 9.9 & 5.2 & 7.1 & 7.4 \\
\hline Yunnan & 7.0 & 8.8 & 7.7 & 9.2 & 8.2 \\
\hline West & 4.8 & 10.7 & 6.7 & 8.2 & 7.7 \\
\hline Tibet $^{2}$ & $\ldots$ & -1.3 & 4.0 & 11.6 & 5.6 \\
\hline Shaanxi & 5.9 & 10.6 & 6.7 & 8.2 & 8.0 \\
\hline Gansu & 1.2 & 10.9 & 6.8 & 8.6 & 7.1 \\
\hline Qinghai & 2.5 & 7.7 & 3.2 & 7.2 & 5.3 \\
\hline Ningxia & 3.6 & 10.3 & 4.8 & 8.8 & 7.0 \\
\hline Xinjiang & 7.6 & 11.9 & 7.8 & 7.5 & 8.7 \\
\hline China & 6.0 & 10.3 & 7.0 & 9.4 & 8.3 \\
\hline $\begin{array}{l}\text { Sources: Stat } \\
\text { Statistical Yearboo } \\
{ }^{1} \text { Data cover } 1 \\
{ }^{2} \text { Data cover } 1\end{array}$ & $\begin{array}{l}\text { tatistical B } \\
\text { arious issu } \\
-97 \text {. } \\
-97 \text {. }\end{array}$ & $\begin{array}{l}\text {; The Gr } \\
\text { ad authors' }\end{array}$ & $\begin{array}{l}\text { Domestic } \\
\text { ulations. }\end{array}$ & t of $C h i$ & 952-95; C \\
\hline
\end{tabular}


Table 3. Regional Economic Indicators, 1978-97

\begin{tabular}{|c|c|c|c|c|}
\hline & \multicolumn{2}{|c|}{$\begin{array}{l}\text { Share of Regional GDP } \\
\text { in Total GDP (Percent) }\end{array}$} & \multicolumn{2}{|c|}{$\begin{array}{l}\text { Share of Regional } \\
\text { Population in Total } \\
\text { Population (Percent) }\end{array}$} \\
\hline & $1978-80$ & 1995-97 & $1978-80$ & 1995-97 \\
\hline North & 14.9 & 12.4 & 11.5 & 11.5 \\
\hline Beijing & 3.1 & 2.4 & 0.9 & 0.9 \\
\hline Tianjin & 2.4 & 1.6 & 0.8 & 0.7 \\
\hline Hebei & 5.2 & 5.1 & 5.3 & 5.4 \\
\hline Shanxi & 2.6 & 1.9 & 2.5 & 2.6 \\
\hline Inner Mongolia & 1.6 & 1.4 & 1.9 & 1.9 \\
\hline Northeast & 13.7 & 10.1 & 9.1 & 8.6 \\
\hline Liaoning & 6.4 & 4.6 & 3.6 & 3.4 \\
\hline Jilin & 2.3 & 1.9 & 2.3 & 2.2 \\
\hline Heilongjiang & 5.0 & 3.5 & 3.3 & 3.1 \\
\hline Coastal & 32.7 & 41.7 & 26.6 & 26.9 \\
\hline Shanghai & 7.4 & 4.3 & 1.2 & 1.1 \\
\hline Jiangsu & 7.4 & 8.8 & 6.1 & 5.9 \\
\hline Zhejiang & 3.9 & 6.1 & 3.9 & 3.6 \\
\hline Fujian & 1.9 & 3.8 & 2.6 & 2.7 \\
\hline Guangdong & 5.4 & 9.5 & 5.3 & 5.7 \\
\hline Shandong & 6.6 & 8.7 & 7.5 & 7.3 \\
\hline Hainan $^{1}$ & $\ldots$ & 0.6 & $\ldots$ & 0.6 \\
\hline Southeast & 19.8 & 19.1 & 26.0 & 26.1 \\
\hline Anhui & 3.3 & 3.5 & 5.0 & 5.0 \\
\hline Jiangxi & 2.6 & 2.2 & 3.3 & 3.4 \\
\hline Henan & 5.0 & 5.3 & 7.4 & 7.6 \\
\hline Hubei & 4.6 & 4.3 & 4.8 & 4.8 \\
\hline Hunan & 4.4 & 3.9 & 5.4 & 5.3 \\
\hline South & 12.8 & 12.0 & 19.8 & 19.3 \\
\hline Guangxi & 2.2 & 2.7 & 3.6 & 3.8 \\
\hline Sichuan & 7.3 & 6.1 & 10.2 & 9.3 \\
\hline Guizhou & 1.4 & 1.1 & 2.8 & 2.9 \\
\hline Yunnan & 2.0 & 2.1 & 3.2 & 3.3 \\
\hline West & 6.0 & 4.8 & 7.0 & 7.5 \\
\hline Tibet $^{2}$ & $\ldots$ & 0.1 & . . & 0.2 \\
\hline Shaanxi & 2.3 & 1.7 & 2.9 & 3.0 \\
\hline Gansu & 1.8 & 1.0 & 2.0 & 2.0 \\
\hline Qinghai & 0.4 & 0.3 & 0.4 & 0.4 \\
\hline Ningxia & 0.4 & 0.3 & 0.4 & 0.4 \\
\hline Xinjiang & 1.2 & 1.4 & 1.3 & 1.5 \\
\hline China & 100.0 & 100.0 & 100.0 & 100.0 \\
\hline
\end{tabular}

Sources: State Statistical Bureau; The Gross Domestic Product of China, 1952-95; China Statistical Yearbook, various issues; and authors' calculations.

${ }^{1}$ Data cover 1985-97.

${ }^{2}$ Data cover 1984-97. 
Figure 2. Regions' Initial Income and Per Capita Growth Increases

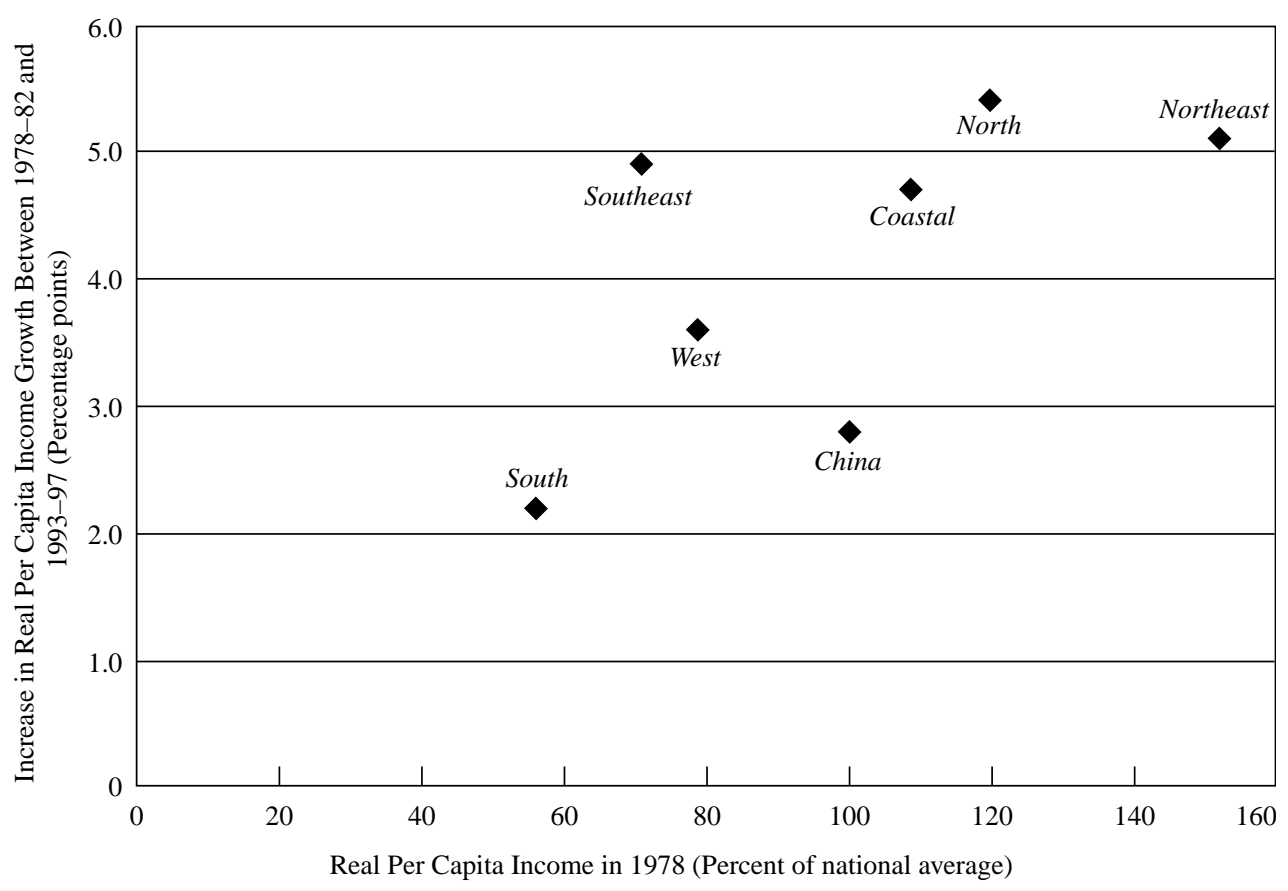

\section{Economic Structure}

A marked transformation in China's economic structure has taken place since the late 1970s. The share of the agricultural sector in GDP has fallen by some 10 percentage points to 20 percent. At the same time, the ratio of total investment to GDP has risen steadily, accompanied by an expansion in investment spending both by state enterprises as well as the nonstate sector.

While the structural transformation at the national level was generally reflected in developments in each of the regions, there was significant variation in the timing, pattern, and extent of transformation across regions. For example, reform of the agricultural sector was initially introduced in Anhui province in 1978, and later adopted in almost all rural farm households by 1984.16 Consequently, the regions with the largest agricultural sectors (southern and southeastern) at the start of the reform process experienced the steepest declines in agriculture's share in regional GDP (Table 4). By contrast, regions where the agricultural sector was relatively small at the outset (northern and northeastern) witnessed a much smaller decline in its share in regional GDP.

Regional differences in the pattern of investment were even more pronounced. The share of total investment in GDP increased sharply in the northern and coastal

\footnotetext{
${ }^{16}$ See Qian (1999).
} 


\begin{tabular}{|c|c|c|c|c|}
\hline \multicolumn{5}{|c|}{$\begin{array}{c}\text { Table 4. Agriculture's Share in GDP } \\
\text { (In percent) }\end{array}$} \\
\hline & $1978-82$ & $1983-87$ & 1988-92 & 1993-97 \\
\hline North & 20.4 & 20.6 & 18.2 & 15.8 \\
\hline Beijing & 5.1 & 7.0 & 8.1 & 5.8 \\
\hline Tianjin & 6.1 & 7.7 & 8.9 & 6.5 \\
\hline Hebei & 31.1 & 30.9 & 22.9 & 20.0 \\
\hline Shanxi & 22.7 & 19.7 & 16.1 & 14.4 \\
\hline Inner Mongolia & 32.5 & 31.9 & 32.3 & 30.2 \\
\hline Northeast & 21.6 & 21.9 & 17.8 & 17.7 \\
\hline Liaoning & 16.3 & 16.6 & 14.9 & 13.8 \\
\hline Jilin & 29.4 & 31.1 & 24.9 & 26.0 \\
\hline Heilongjiang & 24.6 & 24.1 & 18.1 & 18.6 \\
\hline Coastal & 27.9 & 28.2 & 23.1 & 16.0 \\
\hline Shanghai & 3.7 & 4.1 & 3.9 & 2.4 \\
\hline Jiangsu & 31.6 & 31.2 & 23.2 & 16.1 \\
\hline Zhejiang & 37.4 & 29.5 & 23.5 & 15.5 \\
\hline Fujian & 37.1 & 34.2 & 28.3 & 21.6 \\
\hline Guangdong & 32.9 & 31.2 & 24.9 & 15.6 \\
\hline Shandong & 36.6 & 35.9 & 27.8 & 20.0 \\
\hline Hainan $^{1}$ & $\ldots$ & 51.0 & 42.7 & 34.5 \\
\hline Southeast & 43.3 & 40.4 & 34.0 & 27.0 \\
\hline Anhui & 48.2 & 42.3 & 34.0 & 26.8 \\
\hline Jiangxi & 45.2 & 41.4 & 38.1 & 30.6 \\
\hline Henan & 40.9 & 39.2 & 32.1 & 25.1 \\
\hline Hubei & 40.6 & 37.5 & 32.2 & 24.7 \\
\hline Hunan & 43.7 & 42.8 & 36.0 & 30.3 \\
\hline South & 42.9 & 39.6 & 34.6 & 28.3 \\
\hline Guangxi & 45.0 & 43.3 & 37.6 & 30.3 \\
\hline Sichuan & 42.2 & 38.0 & 33.1 & 27.5 \\
\hline Guizhou & 43.2 & 41.4 & 38.6 & 34.8 \\
\hline Yunnan & 42.8 & 39.6 & 33.5 & 24.5 \\
\hline West & 30.4 & 31.8 & 28.0 & 24.2 \\
\hline Tibet $^{2}$ & $\ldots$ & 47.3 & 47.7 & 43.3 \\
\hline Shaanxi & 32.5 & 30.3 & 25.3 & 22.1 \\
\hline Gansu & 22.4 & 27.9 & 25.8 & 23.4 \\
\hline Qinghai & 26.4 & 26.9 & 24.7 & 21.5 \\
\hline Ningxia & 27.3 & 29.8 & 24.9 & 21.4 \\
\hline Xinjiang & 39.5 & 38.9 & 33.9 & 27.2 \\
\hline China & 30.9 & 29.5 & 24.8 & 19.9 \\
\hline $\begin{array}{r}\text { Sources: State } \\
\text { Statistical Yearbook } \\
{ }^{1} \text { Data cover } 19 \\
{ }^{2} \text { Data cover } 19\end{array}$ & $\begin{array}{l}\text { ical Bureal } \\
\text { us issues; at }\end{array}$ & $\begin{array}{l}\text { Gross Dor } \\
\text { ors' calcula }\end{array}$ & Product of & 1952-95; China \\
\hline
\end{tabular}


regions over the period as a whole but less so in the other areas. The western region had the highest share of investment in total output at the start of the sample period (40 percent of GDP), which rose to 50 percent (Table 5). Despite the relatively high investment ratio, however, the large share of output produced by stateowned enterprises (SOEs) - about 75 percent-and constraints in their reform may have led to a buildup of inventories. In the northern and northeastern regions, much of the rise in the investment rate was also on account of SOEs, while the increase in the coastal region was mainly due to the nonstate sector.

The preponderance of SOEs in provincial economies has varied across regions as well. Although data on the share of state enterprises in total industrial output are available only from the late 1980s (Table 6), these indicate a sharp decline in the importance of the state sector in the coastal and southeastern regions. By contrast, SOEs have continued to account for the majority of industrial output in the northeastern and western regions.

\section{Policies Affecting Economic Performance}

Despite restrictions on internal capital mobility, policies have been geared toward attracting capital and technology from abroad. There was a marked shift in China's foreign investment policies in the second half of the 1980s, including the introduction of special tax incentives to encourage investment in certain industries. FDI flows increased sharply from less than US\$1 billion in 1983 to over US $\$ 40$ billion in 1997. The inflows showed a dramatic increase in the coastal region, where they rose to over 9 percent of provincial GDP and accounted for an important source of investment spending (Table 7). More recently, the northern and northeastern regions have also seen a sizable increase in FDI inflows. As illustrated in Figure 3, initially rich provinces have tended to attract relatively greater inflows of FDI.

An important mechanism for reallocating financial capital across provinces has been the pattern of lending by the banking system, which until the mid-1990s was subject to credit quotas set by the State Planning Commission (SPC) in conjunction with the People's Bank of China (PBC). Credit quotas for each province were established on an annual basis to meet policy objectives. Banks in provinces with quotas that were high in relation to their deposit growth financed their lending by borrowing from the $\mathrm{PBC}$, while banks in provinces where credit quotas were relatively tight ended up having to maintain high excess reserves with the PBC. As a result, there was a close link between the credit plan and central bank lending, and the $\mathrm{PBC}$ played an important role in redistributing financial resources across provinces.

These flows of financial capital appear to have reflected redistributive policy objectives rather than consumption-smoothing or differences in rates of return on investment across provinces. Using data covering 1988-93, Lardy (1998) finds that the provincial share of industrial output produced by SOEs was the most important variable explaining variations in provincial loan to deposit ratios, with 


\begin{tabular}{|c|c|c|c|c|}
\hline \multicolumn{5}{|c|}{$\begin{array}{l}\text { Table 5. Ratio of Total Investment to GDP } \\
\text { (In percent) }\end{array}$} \\
\hline & $1978-82$ & $1983-87$ & 1988-92 & 1993-97 \\
\hline North & 30.2 & 41.4 & 44.5 & 51.5 \\
\hline Beijing & 28.4 & 51.9 & 60.2 & 76.4 \\
\hline Tianjin & 31.2 & 42.3 & 49.9 & 57.3 \\
\hline Hebei & 30.1 & 35.4 & 36.2 & 43.0 \\
\hline Shanxi & 31.4 & 44.9 & 42.5 & 40.6 \\
\hline Inner Mongolia & 30.5 & 34.4 & 40.8 & 47.2 \\
\hline Northeast & 25.0 & 34.2 & 37.4 & 37.9 \\
\hline Liaoning & 22.8 & 31.6 & 37.3 & 38.2 \\
\hline Jilin & 30.6 & 35.0 & 39.4 & 41.1 \\
\hline Heilongjiang & 25.1 & 37.5 & 36.5 & 35.4 \\
\hline Coastal & 27.9 & 35.7 & 40.0 & 47.9 \\
\hline Shanghai & 20.9 & 35.5 & 45.3 & 59.3 \\
\hline Jiangsu & 30.4 & 40.6 & 43.7 & 48.5 \\
\hline Zhejiang & 25.9 & 33.1 & 34.5 & 47.9 \\
\hline Fujian & 30.3 & 31.9 & 31.1 & 44.5 \\
\hline Guangdong & 29.2 & 34.9 & 36.6 & 43.6 \\
\hline Shandong & 32.0 & 36.1 & 43.5 & 46.8 \\
\hline Hainan $^{1}$ & $\ldots$ & $\ldots$ & 61.2 & 57.7 \\
\hline Southeast & 26.0 & 31.8 & 34.0 & 39.0 \\
\hline Anhui & 19.8 & 31.7 & 31.9 & 40.3 \\
\hline Jiangxi & 33.4 & 33.3 & 35.6 & 38.2 \\
\hline Henan & 30.3 & 36.4 & 41.1 & 41.0 \\
\hline Hubei & 24.7 & 31.2 & 31.8 & 40.3 \\
\hline Hunan & 22.9 & 25.5 & 28.0 & 34.2 \\
\hline South & 33.3 & 32.0 & 32.1 & 39.4 \\
\hline Guangxi & 29.7 & 30.1 & 29.6 & 36.1 \\
\hline Sichuan & 33.3 & 32.3 & 32.2 & 40.2 \\
\hline Guizhou & 36.2 & 32.3 & 32.4 & 35.8 \\
\hline Yunnan & 35.5 & 32.5 & 33.8 & 43.4 \\
\hline West & 40.4 & 43.1 & 45.8 & 50.6 \\
\hline Tibet $^{2}$ & $\ldots$ & $\ldots$ & 45.9 & 47.1 \\
\hline Shaanxi & 34.5 & 42.7 & 43.2 & 46.7 \\
\hline Gansu & 37.9 & 37.7 & 41.6 & 40.2 \\
\hline Qinghai & 57.5 & 54.1 & 45.0 & 48.7 \\
\hline Ningxia & 54.0 & 58.1 & 57.8 & 51.8 \\
\hline Xinjiang & 44.9 & 47.4 & 53.8 & 63.5 \\
\hline China & 35.1 & 36.0 & 35.7 & 40.6 \\
\hline $\begin{array}{l}\text { Sources: State } \\
\text { Statistical Yearboo } \\
{ }^{1} \text { Data cover } 19 \\
{ }^{2} \text { Data cover } 19\end{array}$ & $\begin{array}{l}\text { cal Bureau } \\
\text { Is issues; an }\end{array}$ & $\begin{array}{l}\text { Gross Do } \\
\text { ors' calculs }\end{array}$ & Product o. & $1952-95$ \\
\hline
\end{tabular}


Table 6. Share of State-Owned Enterprises in Total Industrial Output (In percent)

\begin{tabular}{|c|c|c|}
\hline & 1988-92 & 1993-97 \\
\hline North & 50.7 & 38.3 \\
\hline Beijing & 62.3 & 49.6 \\
\hline Tianjin & 49.5 & 32.0 \\
\hline Hebei & 48.6 & 31.7 \\
\hline Shanxi & 60.5 & 41.5 \\
\hline Inner Mongolia & 74.6 & 58.5 \\
\hline Northeast & 67.4 & 50.2 \\
\hline Liaoning & 59.6 & 41.1 \\
\hline Jilin & 70.4 & 61.2 \\
\hline Heilongjiang & 80.3 & 64.9 \\
\hline Coastal & 41.2 & 22.3 \\
\hline Shanghai & 66.0 & 38.6 \\
\hline Jiangsu & 33.0 & 20.3 \\
\hline Zhejiang & 28.2 & 14.2 \\
\hline Fujian & 43.8 & 20.1 \\
\hline Guangdong & 40.4 & 18.9 \\
\hline Shandong & 41.4 & 27.0 \\
\hline Hainan & 73.5 & 43.3 \\
\hline Southeast & 59.8 & 35.5 \\
\hline Anhui & 57.3 & 28.3 \\
\hline Jiangxi & 64.8 & 45.3 \\
\hline Henan & 54.1 & 33.6 \\
\hline Hubei & 63.1 & 38.8 \\
\hline Hunan & 63.1 & 38.1 \\
\hline South & 68.0 & 45.5 \\
\hline Guangxi & 70.9 & 39.9 \\
\hline Sichuan & 63.3 & 39.5 \\
\hline Guizhou & 77.0 & 64.9 \\
\hline Yunnan & 76.3 & 66.9 \\
\hline West & 75.2 & 65.1 \\
\hline Tibet & 80.8 & 74.6 \\
\hline Shaanxi & 68.9 & 57.1 \\
\hline Gansu & 78.9 & 64.6 \\
\hline Qinghai & 84.0 & 80.2 \\
\hline Ningxia & 78.3 & 67.8 \\
\hline Xinjiang & 80.0 & 75.8 \\
\hline China & 53.7 & 33.0 \\
\hline
\end{tabular}




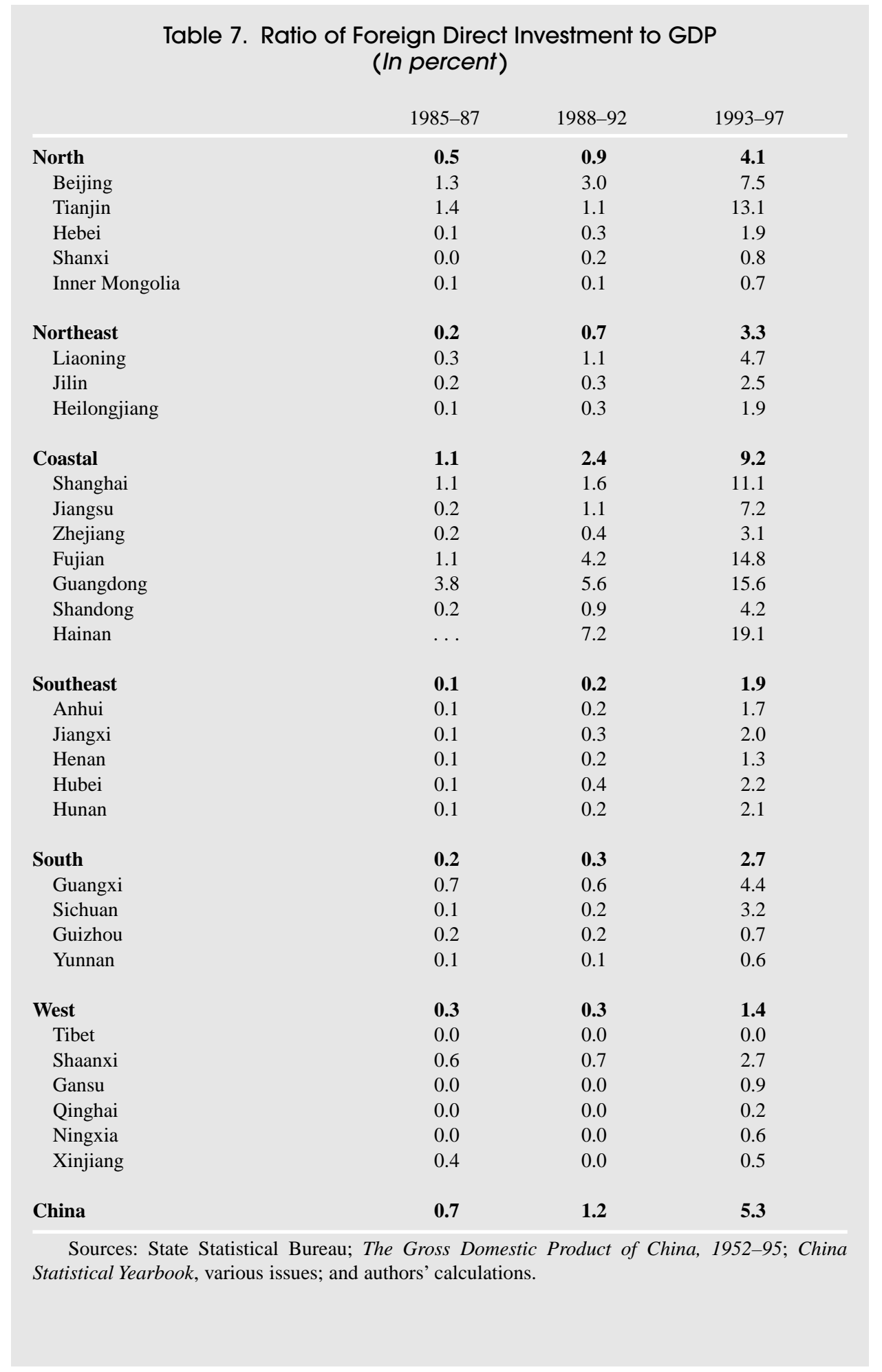


Figure 3. Provinces' Initial Income and FDI Inflows

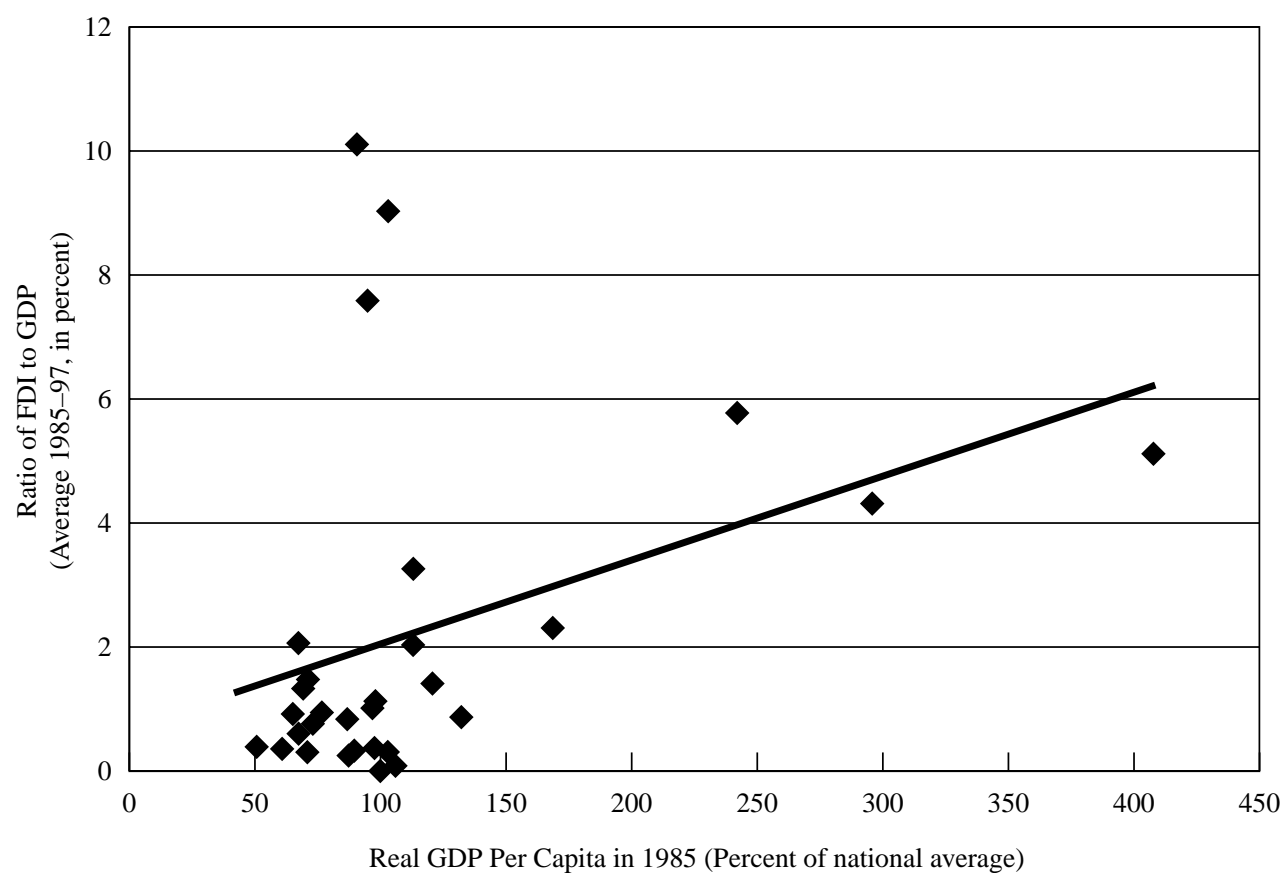

provinces with a high SOE concentration tending to have higher ratios. Since interest rates on loans were administered-generally well below market-clearing levels - and lending was not solely based on commercial factors, provinces with high loan ratios were, in effect, recipients of significant financial transfers. Data on loan-deposit ratios are available for the last two subperiods-1988-92 and 1993-97 (Table 8). The data indicate that the two regions with relatively high shares of industrial output produced by SOEs - the northeast and the west-had among the highest loan-deposit ratios.

As regards fiscal policy, China started in 1979 to devolve authority from the central government to provincial and other forms of local government. The devolution of authority was accompanied by the provision of fiscal incentives. The unified revenue collection and spending system was replaced by a fiscal contracting system. Under the new system, local governments entered into longterm (usually five-year) fiscal contracts with higher level governments and many were allowed to retain 100 percent of the marginal revenue received. Jin, Qian, and Weingast (1999) show that the fiscal contracting system provided provincial governments with strong marginal fiscal incentives. They find a strong correlation between marginal budgetary revenue collection and marginal budgetary expenditure in the 1980s relative to the 1970s. They also find that higher marginal contractual revenue retention rates were associated with faster development of nonstate enterprises and more reform in state enterprises. 


\begin{tabular}{|c|c|c|}
\hline & 1988-92 & 1993-97 \\
\hline North & 1.02 & 0.83 \\
\hline Beijing & 0.65 & 0.51 \\
\hline Tianjin & 1.63 & 1.18 \\
\hline Hebei & 1.14 & 0.93 \\
\hline Shanxi & 1.09 & 1.06 \\
\hline Inner Mongolia & 1.55 & 1.47 \\
\hline Northeast & 1.55 & 1.30 \\
\hline Liaoning & 1.44 & 1.26 \\
\hline Jilin & 1.92 & 1.56 \\
\hline Heilongjiang & 1.49 & 1.22 \\
\hline Coastal & 1.21 & 0.85 \\
\hline Shanghai & 1.34 & 0.83 \\
\hline Jiangsu & 1.30 & 0.86 \\
\hline Zhejiang & 1.09 & 0.83 \\
\hline Fujian ${ }^{1}$ & 1.07 & 0.84 \\
\hline Guangdong & 1.08 & 0.76 \\
\hline Shandong & 1.37 & 1.05 \\
\hline Hainan & 1.29 & 1.02 \\
\hline Southeast & 1.53 & 1.21 \\
\hline Anhui & 1.58 & 1.30 \\
\hline Jiangxi & 1.57 & 1.24 \\
\hline Henan & 1.36 & 1.09 \\
\hline Hubei & 1.74 & 1.30 \\
\hline Hunan & 1.48 & 1.20 \\
\hline South & 1.25 & 1.06 \\
\hline Guangxi $^{2}$ & 1.22 & 0.92 \\
\hline Sichuan & 1.37 & 1.21 \\
\hline Guizhou & 1.30 & 1.27 \\
\hline Yunnan & 0.99 & 0.85 \\
\hline West & 1.24 & 1.10 \\
\hline Tibet & 0.68 & 0.77 \\
\hline Shaanxi & 1.37 & 1.13 \\
\hline Gansu & 1.27 & 1.07 \\
\hline Qinghai & 1.31 & 1.61 \\
\hline Ningxia & 1.42 & 1.20 \\
\hline Xinjiang & 1.05 & 1.02 \\
\hline China & 1.29 & 0.99 \\
\hline \multicolumn{3}{|c|}{$\begin{array}{l}\text { Sources: Lardy (1998); People's Bank of China; Almanac of China's Finance and Banking, } \\
\text { various issues; and authors' calculations. } \\
{ }^{1} \text { Data missing for 1994. } \\
{ }^{2} \text { Data missing for 1994-96. }\end{array}$} \\
\hline
\end{tabular}


The data on provincial revenue and expenditure indicate a strong positive correlation between the provincial revenue to expenditure ratio with per capita income (Table 9). For example, the coastal region and the three municipalities-where per capita incomes are the highest-also have the highest revenue-expenditure ratios. At the same time, these ratios are lowest in the western and southern regions, where per capita incomes are also the lowest. This suggests that fiscal policy has also been used in a redistributive manner.

However, it is important to note several qualifications regarding the provincial fiscal data. First, these data are available only from 1983, and from three different sources that are occasionally inconsistent for overlapping years. ${ }^{17}$ Moreover, they do not appear to include revenue and expenditure by the central government in each province, which could significantly affect the measurement of the redistributive nature of national fiscal policy. To the extent that such taxation and spending were redistributive, their omission from the regression equation could understate the estimated speed of convergence. Finally, the impact of redistributive fiscal policy on growth would depend critically on the form of redistribution. For example, the growth implications of income transfers could be very different from those associated with infrastructure investment.

\section{Estimation Results}

The empirical analysis tests for convergence of per capita incomes across provinces by estimating a growth equation that is derived as a log-linear approximation of the transition path of per capita output around its steady state level. ${ }^{18}$ The equation, given below, specifies the average growth rate of per capita output over the interval $t-T$ and $t$ as a function of initial output and other variables.

$$
\ln \left(y_{i t} / y_{i t-T}\right)=C-\left(1-e^{-\beta T}\right) \ln \left(y_{i t-T}\right)+x_{i t}+\varepsilon_{i t},
$$

where $i$ indexes the province, $T$ is the length of the observation interval, $t$ is time period, $y_{i t-T}$ is real per capita output at time $t-T$, the beginning of the subperiod, $y_{i t}$ is real per capita income at time $t$, and $\beta$ is the convergence coefficient. The convergence coefficient $(\beta)$ indicates the rate at which $y_{i t-T}$ approaches the steady state level of GDP per capita. A positive coefficient implies that the poorer provinces grow faster than the richer ones. The higher is $\beta$, the more rapid is the convergence to steady state. The variable $C$ is the constant term common across provinces, $x_{i t}$ includes the vector of other explanatory variables, and $\varepsilon_{i t}$ is an independent error term.

The usual role of the explanatory variables is to capture the structural characteristics of the economy that determine the steady state level of per capita income. Traditional variables included in the cross-country growth literature are

\footnotetext{
${ }^{17}$ See Appendix I for a list of the data sources.

${ }^{18}$ The equation for the rate of economic growth is based on the Mankiw, Romer, and Weil (1992) version of the Solow-Swan model. See also Solow (1956) and Swan (1956).
} 


\section{Table 9. Fiscal Revenue to Expenditure Ratio}

\begin{tabular}{|c|c|c|c|}
\hline & $1983-87$ & 1988-92 & 1993-97 \\
\hline North & 1.09 & 0.95 & 0.69 \\
\hline Beijing & 1.59 & 1.17 & 0.65 \\
\hline Tianjin & 1.83 & 1.23 & 0.85 \\
\hline Hebei & 1.10 & 0.97 & 0.71 \\
\hline Shanxi & 0.82 & 0.92 & 0.69 \\
\hline Inner Mongolia & 0.34 & 0.53 & 0.54 \\
\hline Northeast & 1.09 & 0.96 & 0.69 \\
\hline Liaoning & 1.62 & 1.20 & 0.78 \\
\hline Jilin & 0.66 & 0.73 & 0.56 \\
\hline Heilongjiang & 0.77 & 0.84 & 0.65 \\
\hline Coastal & 1.78 & 1.16 & 0.83 \\
\hline Shanghai & 4.93 & 2.07 & 1.05 \\
\hline Jiangsu & 1.82 & 1.30 & 0.83 \\
\hline Zhejiang & 1.58 & 1.29 & 0.93 \\
\hline Fujian $^{1}$ & 0.79 & 0.85 & 0.84 \\
\hline Guangdong & 0.99 & 0.95 & 0.82 \\
\hline Shandong & 1.24 & 0.86 & 0.64 \\
\hline Hainan $^{2}$ & & 0.35 & 0.78 \\
\hline Southeast & 1.00 & 0.89 & 0.70 \\
\hline Anhui & 0.93 & 0.83 & 0.82 \\
\hline Jiangxi & 0.71 & 0.76 & 0.70 \\
\hline Henan & 1.01 & 0.92 & 0.68 \\
\hline Hubei & 1.20 & 0.96 & 0.69 \\
\hline Hunan & 1.02 & 0.90 & 0.67 \\
\hline South & 0.76 & 0.85 & 0.73 \\
\hline Guangxi $^{3}$ & 0.65 & 0.85 & 0.57 \\
\hline Sichuan & 0.93 & 0.88 & 0.74 \\
\hline Guizhou & 0.58 & 0.76 & 0.54 \\
\hline Yunnan & 0.69 & 0.84 & 0.55 \\
\hline West & 0.46 & 0.59 & 0.51 \\
\hline Tibet & -0.05 & 0.05 & 0.06 \\
\hline Shaanxi & 0.72 & 0.77 & 0.68 \\
\hline Gansu & 0.68 & 0.73 & 0.60 \\
\hline Qinghai & 0.24 & 0.43 & 0.39 \\
\hline Ningxia & 0.29 & 0.44 & 0.43 \\
\hline Xinjiang & 0.31 & 0.47 & 0.43 \\
\hline China & 1.13 & 0.94 & 0.73 \\
\hline
\end{tabular}

Sources: World Bank (1994); People's Bank of China; Almanac of China's Finance and Banking, various issues; State Statistical Bureau; China Statistical Yearbook, various issues; and authors' calculations.

${ }^{1}$ Data missing for 1991.

${ }^{2}$ Data cover 1988-97.

${ }^{3}$ Data missing for 1993-94. 
the investment rate and educational characteristics. While time series data on educational characteristics by province or region were not available, we included the share of investment to provincial GDP and the private-public mix of production, as reflected in the share of SOEs in industrial output, in the regressions. As highlighted above, the dominance of SOEs in industrial production has varied sharply across the regions. Structural and institutional reforms that improve economic incentives and resource allocation and remove impediments to private sector development are likely to increase the productive capacity of the economy and have an effect on economic growth. ${ }^{19}$

The remaining variables included in the analysis are policy variables that appear to be particularly relevant in the Chinese context. These include the share of FDI flows to provincial GDP, the ratio of revenue to expenditure, and the ratio of bank loans to deposits. ${ }^{20}$ As noted earlier, higher FDI flows could imply either more openness, and thereby a higher rate of convergence, or access to different technology, implying convergence to a different steady state, at least in the short run. The rate of convergence would also be affected by the extent of the redistributive nature of bank lending and provincial fiscal policies.

The equation is estimated separately for each subperiod (1978-82, 1983-87, 1988-92, 1993-97) and for the entire sample period. The estimation results for each subperiod are based on iterative, nonlinear least squares that allow for heteroskedasticity in the subperiods. For the full sample, the estimates are derived using the seemingly unrelated regression approach (SURE), which also allows for correlation of the error terms across the subperiods. For comparison, pooled nonlinear regressions with regional and time dummies were also estimated over the corresponding sample period. As shown below, there is little difference in the full sample estimates except for the estimation results for the period 1988-97. Since data on all the explanatory variables are not available for the entire period, the estimation results are presented for different sample periods (Tables 10, 11, and 12).

\section{Sample Period 1978-97}

The first column of Table 10 shows the regression estimates of the convergence coefficient $(\beta)$, based on equation (1) where the explanatory variables include only a constant and the log of each province's initial per capita income in that subperiod. Rows 1-4 of column 1 present the results for each subperiod.

The estimate of $\beta$ in the first subperiod, 1978-82, is 0.016 or 1.6 percent and is positively significant. This implies that 1.6 percent of the gap between current output

\footnotetext{
${ }^{19}$ See Khan (1987) for a review of the nature and evidence for such an effect.

${ }^{20}$ The loan to deposit ratio is intended to capture the redistributive nature of bank lending, or the extent to which the banking system was a net borrower or net lender in a particular province. Another possibility would be to consider credit availability, measured as the change in real credit, scaled by provincial GDP. Such a variable would be highly correlated with investment, however, and its construction is complicated by the use of multiple sources of data for bank loans and deposits.
} 


\begin{tabular}{|c|c|c|c|c|c|c|c|}
\hline \multicolumn{8}{|c|}{ Table 10. Estimation Results, 1978-97 } \\
\hline & \multirow{2}{*}{\multicolumn{2}{|c|}{ (1) }} & \multirow{2}{*}{\multicolumn{2}{|c|}{ (2) }} & \multicolumn{3}{|c|}{ (3) } \\
\hline & & & & & & & \\
\hline & Beta & $R^{2}$ & Beta & $R^{2}$ & Beta & Investment & $R^{2}$ \\
\hline $1978-82$ & $\begin{array}{r}0.016^{*} \\
(0.005)\end{array}$ & $\begin{array}{l}0.123 \\
0.086\end{array}$ & $\begin{array}{c}0.020 * \\
(0.005)\end{array}$ & $\begin{array}{l}0.658 \\
0.06\end{array}$ & $\begin{array}{c}0.021 * \\
(0.006)\end{array}$ & $\begin{array}{c}-0.0257 \\
(0.065)\end{array}$ & $\begin{array}{l}0.66 \\
0.061\end{array}$ \\
\hline $1983-87$ & $\begin{array}{c}0.005 \\
(0.005)\end{array}$ & $\begin{array}{l}0.015 \\
0.078\end{array}$ & $\begin{array}{c}0.018 * \\
(0.008)\end{array}$ & $\begin{array}{l}0.398 \\
0.068\end{array}$ & $\begin{array}{l}0.017 * * \\
(0.010)\end{array}$ & $\begin{array}{l}-0.046 \\
(0.124)\end{array}$ & $\begin{array}{l}0.402 \\
0.069\end{array}$ \\
\hline 1988-92 & $\begin{array}{l}-0.003 \\
(0.004)\end{array}$ & $\begin{array}{l}0.009 \\
0.072\end{array}$ & $\begin{array}{c}0.008 \\
(0.006)\end{array}$ & $\begin{array}{l}0.557 \\
0.053\end{array}$ & $\begin{array}{c}0.007 \\
(0.007)\end{array}$ & $\begin{array}{c}-0.014 \\
(0.067)\end{array}$ & $\begin{array}{l}0.558 \\
0.055\end{array}$ \\
\hline 1993-97 & $\begin{array}{c}-0.017 * \\
(0.006)\end{array}$ & $\begin{array}{l}0.162 \\
0.083\end{array}$ & $\begin{array}{l}-0.004 \\
(0.007)\end{array}$ & $\begin{array}{l}0.721 \\
0.053\end{array}$ & $\begin{array}{c}0.001 \\
(0.011)\end{array}$ & $\begin{array}{c}0.056 \\
(0.106)\end{array}$ & $\begin{array}{l}0.724 \\
0.054\end{array}$ \\
\hline $\begin{array}{l}\text { Restricted (SURE) } \\
\text { coefficients }\end{array}$ & $\begin{array}{c}0.001 \\
(0.003)\end{array}$ & & $\begin{array}{l}0.011 * * \\
(0.005)\end{array}$ & & $\begin{array}{c}0.013 * \\
(0.004)\end{array}$ & $\begin{array}{r}0.062^{*} \\
(0.029)\end{array}$ & \\
\hline $\begin{array}{l}\text { Restricted (NLOLS) } \\
\text { coefficients }\end{array}$ & $\begin{array}{c}-0.0002 \\
(0.003)\end{array}$ & $\begin{array}{l}0.49 \\
0.082\end{array}$ & $\begin{array}{c}0.011 * \\
(0.004)\end{array}$ & $\begin{array}{l}0.72 \\
0.062\end{array}$ & $\begin{array}{c}0.013 * \\
(0.004)\end{array}$ & $\begin{array}{l}0.059 * * \\
(0.034)\end{array}$ & $\begin{array}{l}0.73 \\
0.062\end{array}$ \\
\hline $\begin{array}{l}\text { Wald test } \\
\text { Chi square }\end{array}$ & 24.482 & & 7.142 & & 6.939 & & \\
\hline Degrees of freedom & 3 & & 3 & & 6 & & \\
\hline$p$-value & 0.000 & & 0.068 & & 0.327 & & \\
\hline Chi square $(0.05)$ & 7.815 & & 7.815 & & 12.592 & & \\
\hline Degrees of freedom & 3 & & 3 & & 6 & & \\
\hline
\end{tabular}

Notes: Standard errors in parentheses; $*$ denotes significance at the 5 percent level, ** at the 10 percent level.

per capita and the steady state per capita output is closed in one year. However, the estimates for the second and third subperiods are insignificant, while the estimated convergence coefficient in the fourth subperiod is negatively significant. Large FDI flows, which surged in the fourth period into the northern and coastal regions, may be viewed as a positive shock that benefited the richer provinces. ${ }^{21}$ If the estimate of $\beta$ is constrained to be the same for all subperiods, the resulting joint estimate of $\beta$ is 0.001 and is not significant. However, a Wald test for the equality of the coefficients across the subperiods rejects the hypothesis that $\beta$ is stable over the subperiods.

\footnotetext{
${ }^{21}$ Barro and Sala-i-Martin (1992a) find that the estimated speed of convergence in the U.S. was negative over the period 1920-30. This was attributed to large declines in the relative price of agricultural commodities that affected the poorer agricultural states adversely.
} 
Column 2 of Table 10 presents the estimated speed of convergence when regional dummies are incorporated. These dummies proxy for differences in the steady state levels of per capita income to which the provinces of China are converging. Six regional dummies are included for the different regions discussed before- the north, northeast, coastal, south, southeast, and west. The inclusion of regional dummies improves the fit of the estimated equations over the subperiods suggesting that regional differences are significant. ${ }^{22}$ The estimated value of the convergence coefficient over the subperiod 1978-82 increases from 0.016 to 0.02 and is positively significant. The estimated coefficient for the subperiod 1983-88 also becomes positively significant $(\beta=0.018)$. However, the coefficients in the third and fourth subperiods are insignificant. The estimate of the restricted $\beta$ increases to 0.011 or an estimated rate of convergence of 1.1 percent. The Wald test for equality of the coefficients suggests that the hypothesis of a stable $\beta$ across the subperiods can still be rejected at the 5 percent level, but not at the 10 percent level.

In contrast to the Barro and Sala-i-Martin (1991, 1992a, and 1992b) results for U.S. states, Japanese prefectures, and eight European economies, these estimations do not provide support for the hypothesis of unconditional convergence. Rather, these results suggest that regions of China are converging to different steady state levels of per capita income.

Column 3 of Table 10 includes the ratio of total investment to provincial GDP in the estimations. While this coefficient is not significant for the subperiods, the hypothesis of equality of these coefficients across the subperiods cannot be rejected using the Wald test, and the restricted coefficient for total investment is positively significant. Moreover, the inclusion of this variable affects the estimated rate of convergence, which increases to 1.3 percent in the combined regression and is now significant at the 5 percent level. ${ }^{23}$

\section{Sample Period 1983-97}

Since data on FDI flows and revenue and expenditure at the provincial level are not available prior to 1983 , the relationship between these variables and per capita growth was examined over the sample 1983-97.24 Table 11 presents these results. The inclusion of the FDI variable leads to an increase in the estimated rate of convergence in the 1983-87 and 1993-97 subperiods. The Wald test again indicates that the hypothesis of restricted coefficients over the subperiods cannot be rejected. ${ }^{25}$

${ }^{22}$ However, these differences do not appear to be significant at the provincial level. Estimations using fixed effects for each province to test whether each province was converging to its own steady state were not supported by the data.

${ }^{23}$ Khan and Kumar (1997) also examine the effect of investment on the speed of convergence for a sample of developing countries. They find that the higher the ratio of investment to GDP, the higher is the rate of growth of per capita income. The estimated size of the convergence coefficient, taking into account regional differences, is 1.4 percent, which is very close to the estimated convergence coefficient for China.

${ }^{24}$ Average levels of the FDI flows over 1985-87 are used for the second subperiod under the assumption that the level of FDI flows was close to zero in 1983 and 1984.

${ }^{25}$ While the estimated coefficients of this equation may, in principle, be affected by collinearity between total investment and FDI, there was actually very little correlation between the two variables over the sample period. 


\begin{tabular}{|c|c|c|c|c|c|c|c|c|c|}
\hline \multicolumn{10}{|c|}{ Table 11. Estimation Results, 1983-97 } \\
\hline & \multicolumn{4}{|c|}{ (1) } & \multicolumn{5}{|c|}{ (2) } \\
\hline & Beta & $\begin{array}{c}\text { Total } \\
\text { Investment }\end{array}$ & FDI & $R^{2}$ & Beta & $\begin{array}{c}\text { Total } \\
\text { Investmen }\end{array}$ & it FDI $\mathrm{F}$ & $\operatorname{Rev} / \operatorname{Exp}$ & $R^{2}$ \\
\hline $1983-87$ & $\begin{array}{c}0.025^{*} \\
(0.008)\end{array}$ & $\begin{array}{c}0.225^{*} \\
(0.080)\end{array}$ & $\begin{array}{c}0.020^{*} \\
(0.008)\end{array}$ & $\begin{array}{l}0.49 \\
0.065\end{array}$ & $\begin{array}{c}0.034^{*} \\
(0.009)\end{array}$ & $\begin{array}{c}0.057 \\
(0.083)\end{array}$ & $\begin{array}{c}0.019^{*} \\
(0.007)\end{array}$ & $\begin{array}{c}0.035 \\
(0.025)\end{array}$ & $\begin{array}{l}0.51 \\
0.066\end{array}$ \\
\hline $1988-92$ & $\begin{array}{c}0.011 \\
(0.008)\end{array}$ & $\begin{array}{l}0.003 \\
0.061\end{array}$ & $\begin{array}{c}0.009 \\
(0.011)\end{array}$ & $\begin{array}{l}0.57 \\
0.055\end{array}$ & $\begin{array}{c}0.011 \\
(0.011)\end{array}$ & $\begin{array}{c}0.003 \\
(0.062)\end{array}$ & $\begin{array}{c}0.009 \\
(0.011)\end{array}$ & $\begin{array}{c}-0.001 \\
(0.048)\end{array}$ & $\begin{array}{l}0.57 \\
0.057\end{array}$ \\
\hline 1993-97 & $\begin{array}{l}0.017 * * \\
(0.009)\end{array}$ & $\begin{array}{c}0.128 \\
(0.094)\end{array}$ & $\begin{array}{c}0.032 * \\
(0.011)\end{array}$ & $\begin{array}{l}0.78 \\
0.05\end{array}$ & $\begin{array}{c}0.022^{* *} \\
(0.013)\end{array}$ & $\begin{array}{c}0.175 \\
(0.116)\end{array}$ & $\begin{array}{l}0.024 * * \\
(0.015)\end{array}$ & $\begin{array}{c}0.081 \\
(0.080)\end{array}$ & $\begin{array}{l}0.79 \\
0.05\end{array}$ \\
\hline $\begin{array}{l}\text { Restricted } \\
\text { (SURE) } \\
\text { coefficients }\end{array}$ & $\begin{array}{c}0.018^{*} \\
(0.006)\end{array}$ & $\begin{array}{l}0.100 * * \\
(0.055)\end{array}$ & $\begin{array}{c}0.019 * \\
(0.006)\end{array}$ & & $\begin{array}{c}0.019 * \\
(0.007)\end{array}$ & $\begin{array}{c}0.106^{*} \\
(0.053)\end{array}$ & $\begin{array}{c}0.019^{*} \\
(0.006)\end{array}$ & $\begin{array}{c}0.006 \\
(0.027)\end{array}$ & \\
\hline $\begin{array}{l}\text { Restricted } \\
\text { (NLOLS) } \\
\text { coefficients }\end{array}$ & $\begin{array}{c}0.020^{*} \\
(0.007)\end{array}$ & $\begin{array}{c}0.109^{*} \\
(0.055)\end{array}$ & $\begin{array}{c}0.020^{*} \\
(0.007)\end{array}$ & $\begin{array}{l}0.74 \\
0.06\end{array}$ & $\begin{array}{c}0.019 * \\
(0.007)\end{array}$ & $\begin{array}{c}0.109^{*} \\
(0.052)\end{array}$ & $\begin{array}{c}0.020^{*} \\
(0.007)\end{array}$ & $\begin{array}{l}-0.001 \\
(0.024)\end{array}$ & $\begin{array}{l}0.74 \\
0.06\end{array}$ \\
\hline $\begin{array}{l}\text { Wald test } \\
\text { Chi square } \\
\text { Degrees of } \\
\text { freedom }\end{array}$ & 6.488 & & & & $\begin{array}{l}8.83 \\
8\end{array}$ & & & & \\
\hline$p$-value & 0.371 & & & & 0.357 & & & & \\
\hline $\begin{array}{l}\text { Chi square } \\
(0.05) \\
\text { Degrees of } \\
\text { freedom }\end{array}$ & $\begin{array}{c}12.592 \\
6\end{array}$ & & & & $\begin{array}{c}15.507 \\
8\end{array}$ & & & & \\
\hline $\begin{array}{r}\text { Notes: S } \\
\text { percent level. }\end{array}$ & tandard e & rors in pare & theses; & denot & gnificance & at the $5 \mathrm{p}$ & ercent lev & vel, ** & the 10 \\
\hline
\end{tabular}

The estimates indicate that FDI flows appear to be positively related to per capita income growth, implying that capital mobility appears to have had a strong effect on the rate of convergence. The estimated rate of convergence increases to 1.8 percent - broadly comparable to results obtained by Barro and Sala-i-Martin of around 2 percent for the U.S., Japan, and Europe. The estimate obtained for China implies that it takes 38 years to eliminate one-half of the initial gap in per capita incomes. ${ }^{26}$

The ratio of revenue to expenditure for the provinces appears to have little relation to per capita growth. These results may be due to the problems surrounding the provincial fiscal data noted above, and to the fact that the ratios used are average

${ }^{26}$ The time $t$ for which $\log (y(t))$ is halfway between $\log (y(0))$ and $\log \left(y^{*}\right)$ satisfies the condition $e^{-\beta t}=1 / 2$. The half-life is therefore $\log (2) / \beta=0.69 / \beta$. Hence, if $\beta=0.018$, then the half-life is 38 years. 


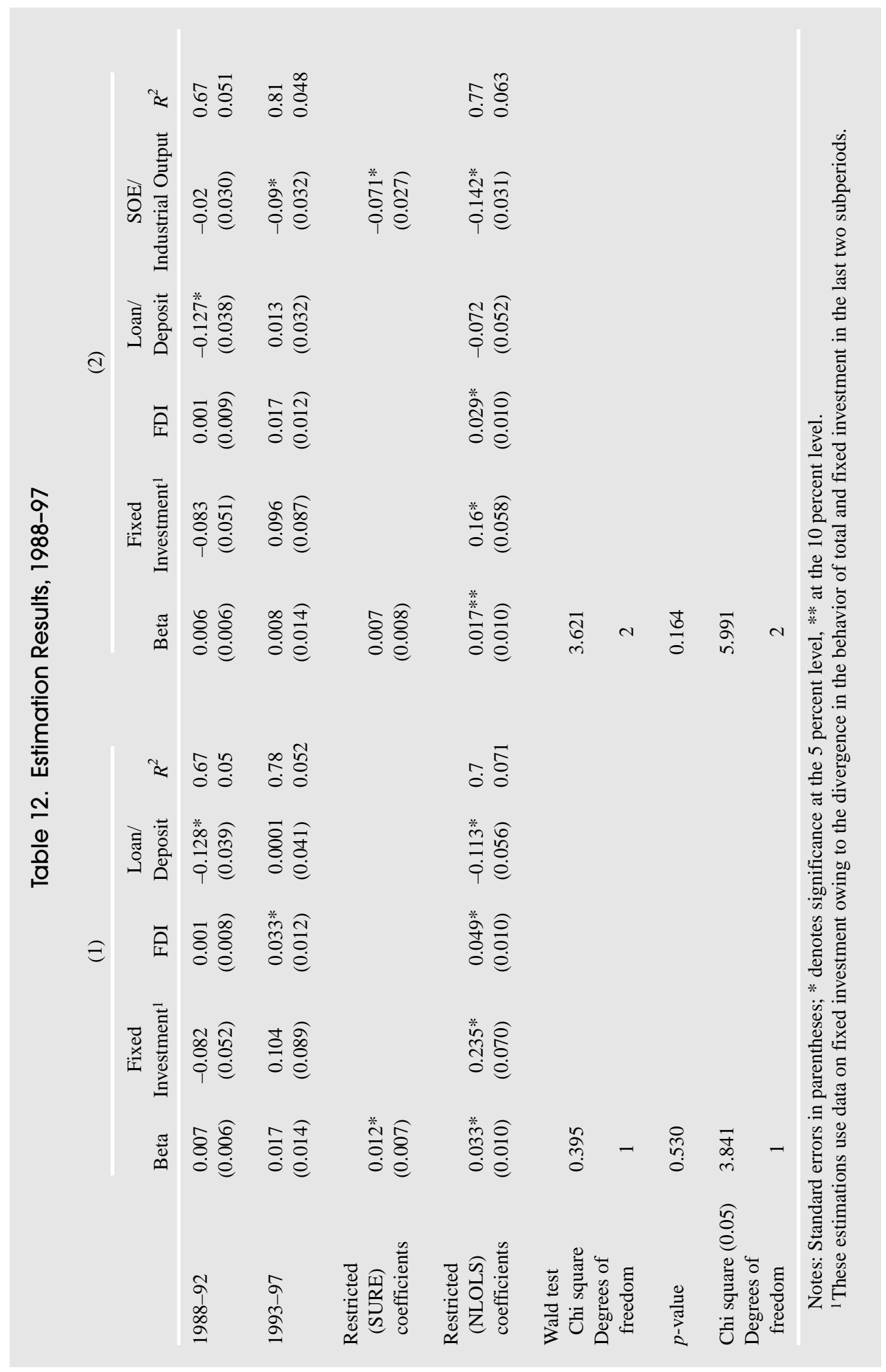


revenue to expenditure rather than marginal revenue to expenditure as mentioned by Jin, Qian, and Weingast (1999). Moreover, revenue contracting practices between different levels of government were subject to frequent negotiation and change. Institutional changes in 1992-94, which included a shift towards formal fiscal federalism, may also have affected these results.

\section{Sample Period 1988-97}

In order to incorporate data on loan-deposit ratios and the share of SOEs in industrial output — which are only available from the late 1980s — the regressions were estimated over a further restricted sample period spanning 1988-97. ${ }^{27}$ The constraints imposed by the small sample period, however, are reflected in the estimation results. The variables appear to behave differently over the two subperiods 1988-92 and 1993-97. Therefore, the Wald test rejects the hypothesis that all coefficients are similar across the subperiods. The results suggest that the estimate of a stable $\beta$ coefficient and for the share of SOEs in total industrial output across the subperiods cannot be rejected, but the coefficients on the other variables are different across these periods. These results are shown in Table 12.

In contrast to the FDI flows, the loan-deposit ratio appears to have a negative impact on growth. The loan-deposit ratio is negatively significant over the 1988-92 subperiod. This may be due to the fact that SOEs-which faced soft budget constraints and did not invest on purely commercial principles-received the bulk of the credit from state banks. Nonstate enterprises, by contrast, received only limited credit and faced much harder budget constraints. In the late 1980s and the early 1990s, loans to SOEs accounted for about 80 percent of all nonagricultural loans, while loans to the nonstate sector consisting of township and village enterprises (TVEs) accounted for only about 8 percent of nonagricultural loans. ${ }^{28}$ Hence, the negative relationship between the loan-deposit ratio and growth could be due to the fact that these transfers tended to support inefficient SOEs and thereby dampened growth.

If the share of SOEs in total industrial output is included in the estimations, this ratio is negatively significant in the subperiod 1993-97. The negative coefficient for the share of SOEs in total output in the pooled estimations also suggests that the higher this share, the lower was the rate of economic growth. Hence, the results appear to suggest that enhanced commercial orientation of the SOEs and changes in bank lending policies could have an important positive effect on long-run growth.

\footnotetext{
${ }^{27}$ Instead of total investment in provincial GDP, the share of fixed investment in provincial GDP is used as an explanatory variable as these two measures began to diverge in the 1990s.

${ }^{28}$ People's Bank of China (1993).
} 


\section{Conclusions}

The estimation results indicate that the regions of China are converging, but to different steady state levels of income. The pattern of FDI flows-and the associated technology transfer-appears to have a strong effect on the results. The relatively rich coastal and north/northeastern regions, though perhaps more expensive (in terms of labor costs) than the inland regions, were probably able to attract more FDI precisely because of their relative prosperity and, consequently, more developed infrastructure. The resulting FDI flows boosted the speed of convergence, albeit—at least in the short run - to different steady states for the different regions.

The results suggest that structural characteristics of the regions also appear to have been important factors determining growth and convergence. For example, the total investment rate appears to be positively correlated with growth, while the prevalence of SOEs and high bank loan-deposit ratios tend to be associated with lower growth. These findings would seem to imply that enhanced commercial orientation of production and the banking system is likely to have a positive impact on growth.

The disparity in provincial/regional incomes and the observed convergence to different steady states may also be related to the gradual and experimental nature of market-oriented reforms in China. As noted by Bell, Khor, and Kochhar (1993), reform measures tended to be introduced on an experimental basis in some localities - often as a result of local initiatives — and expanded to a national scale only when they had proved successful at the local level. The decentralization of authority led local governments to assume greater responsibility for state fixed investment, initially in industry, but later in infrastructure as well. ${ }^{29}$ The introduction of agricultural reform and the establishment of special economic zones were also based on local experimentation. In addition, local governments played an important role in attracting foreign investment into their localities. Hence, this pattern of development may give rise to strong local effects in the estimation results. Unless localities within regions tended to adopt reforms at the same time, however, such effects would not be able to explain estimated regional differences in steady state income levels.

\section{APPENDIX I}

\section{Data Sources and Description}

Data on provinces' real and nominal GDP, GDP per capita, agriculture share of GDP, total investment, and fixed investment were taken from The Gross Domestic Product of China, 1952-95, and from various issues of the annual China Statistical Yearbook. Provincial population data were calculated by dividing GDP by GDP per capita; implicit GDP deflators for each province were calculated from the nominal and real GDP series.

Data on provinces' industrial output, industrial output of SOEs, and foreign direct investment were taken from various issues of the China Statistical Yearbook.

\footnotetext{
${ }^{29}$ See, for example, Qian (1999), Bell, Khor, and Kochhar (1993), and Tseng and others (1994).
} 
Data on bank deposits and loans in each province were taken from Lardy (1998) for 1988-93, and from various issues of the annual Almanac of China's Finance and Banking for 1994-97. Data for 1997 refer only to loans and deposits with the four state commercial banks, which account for around three-quarters of total bank loans and deposits.

Data on provincial revenues and expenditures were taken from World Bank (1994) for 1983-90, from various issues of the Almanac of China's Finance and Banking for 1991-94, and from various issues of the China Statistical Yearbook for 1995-97. As noted above, these data do not appear to include central government revenues and expenditures in each province. Moreover, data from the different sources are occasionally inconsistent for years for which overlapping observations are available.

\section{APPENDIX II Labor and Capital Mobility}

\section{Labor Mobility}

The mobility of labor across China's provinces - and indeed from rural to urban areas within provinces-has been limited by policy and institutional factors. Under the household registration system, adopted in 1948, households were designated as either urban or rural; urban households were granted the right to reside in cities and small towns, access to state subsidized grain supplies, and employment in state enterprises. The 1958 Regulation on the Registration of Households required households to register their place of residence and to gain permission for any change in residence. Such permission has generally been difficult to obtain.

Following the adoption of agricultural reforms in 1980, rural households' mobility increased somewhat. Communes were disbanded and households no longer had to meet commune production quotas. The new household responsibility system allowed rural households to determine their allocation of labor between farm and nonfarm activities, which in principle meant that household members could leave the land. However, permission to move under the household registration system remained strictly limited, implying that rural residents could not legally reside in urban areas. In addition, migration without permission was extremely difficult, as it involved forgoing the benefits that legal residence carried, including food rations, housing, access to schooling for children, and a formal system of old age security. While food and housing have become increasingly available on a market basis over the past decade, unregistered migration remains constrained.

Notwithstanding the impediments to urban migration, the number of migrants has increased steadily, particularly since the mid-1980s, when the growth in rural incomes began to taper off as the initial boost from rural reforms subsided. Estimates of the total number of migrants range from 30 million to 200 million; the World Bank estimated, extrapolating on the basis of survey data, the total at 40 million in the mid-1990s. This excluded an additional estimated 30 million workers who commuted from rural to urban areas on a daily basis. ${ }^{30}$

The limited mobility of labor has been reflected in data on provinces' shares in China's total population, which have remained virtually unchanged over the past two decades (see Table 3). While these data do not capture unregistered migration, much of this has likely been from rural to urban areas within provinces rather than across provinces. Hence, such migration is not likely to have altered the provincial population shares in a substantial manner. 


\section{Capital Mobility}

In addition to limiting the mobility of labor, government policies have, in effect, had a dampening impact on the mobility of capital across provinces. Empirical evidence supports the hypothesis that interprovincial capital mobility has indeed been limited.

\section{Tax policies}

The profit retention system, which was in place in the early 1980s, discouraged regional capital mobility. ${ }^{31}$ Under this system, enterprises' transfers to other locations resulted in a loss in profits accruing to the local government, as retained profits were part of local revenue. In 1983-84, modifications to the revenue-sharing system — which involved the decentralization of plan formulation, lowering of plan production targets, and permission to sell above plan output on the market-resulted in a sharp increase in enterprise investment, although the incentive to retain funds within local jurisdictions remained high.

In the late $1980 \mathrm{~s}$, following the introduction of the contract responsibility system, which fixed profit remittances by enterprises, and a system of revenue-sharing between different levels of government, localities have increasingly offered incentives to attract investment. Indeed, according to the World Bank (1994), there has been a proliferation of tax exemptions offered by localities once they have arranged to fulfill their revenue target specified in the contract with the level of government directly above. ${ }^{32}$ As a result, the interregional capital mobility that does take place is based on tax differentials rather than differentials in resource endowments or cost advantages.

\section{Empirical tests of capital mobility}

Empirical evidence presented by Zhao (1998) supports the view that the degree of capital mobility within China is limited, and that the interprovincial capital flows that have taken place have not generally reflected optimizing behavior by investors seeking to equalize rates of return on investment. The empirical tests are based on the proposition that, under perfect capital mobility, an increase in a province's saving rate should be reflected in an increase in all provinces' investment rates, since saving would flow to all provinces to equalize the rates of return on investment.

Zhao (1998) finds that the correlation between provinces' saving and investment rates have generally been high, suggesting that capital has not been freely mobile across provinces. The high correlations remain even after adjusting for the effect of common factors on saving and investment rates. Zhao also finds that correlations were somewhat lower in provinces where the share of investment in the state enterprise sector was large, suggesting that the capital that moved across provincial boundaries was that of the state-owned sector, in which optimizing investment decisions are likely to have played a relatively small role. Conversely, in provinces with the highest shares of private investment in total investment - such as the coastal provinces - the correlation between saving and investment rates was particularly high. Adjusting for this effect, the degree of integration-capital mobility-across provinces is small.

${ }^{30}$ World Bank (1997). Jian, Sachs, and Warner (1996) estimate the total number of migrants at $100-150$ million.

${ }^{31} \mathrm{~A}$ detailed discussion of the institutional aspects of taxation policy and its effect on interregional capital mobility is contained in World Bank (1994).

${ }^{32}$ The World Bank (1994) estimates that there were 1,800 special zones granting tax concessions at the county level or above in early 1993. 


\section{CENTRIPETAL FORCES IN CHINA'S ECONOMIC TAKEOFF}

\section{REFERENCES}

Aziz, Jahangir, and Christoph Duenwald, 2001, "China's Provincial Growth Dynamics," IMF Working Paper 01/3 (Washington: International Monetary Fund).

Barro, Robert J., and Xavier Sala-i-Martin, 1991, "Convergence Across States and Regions," Brookings Papers on Economic Activity, 1, pp. 107-82 (Washington: Brookings Institution).

—_, 1992a, “Convergence,” Journal of Political Economy, Vol. 100 (April), pp. 223-51.

, 1992b, "Regional Growth and Migration: A Japan-United States Comparison," Journal of Japanese and International Economics, Vol. 6 (December), pp. 312-46.

— 1995, Economic Growth (New York: McGraw-Hill).

Bell, Michael W., Hoe Ee Khor, and Kalpana Kochhar, 1993, China at the Threshold of a Market Economy, IMF Occasional Paper 107 (Washington: International Monetary Fund).

Ben-David, Dan, 1993, “Equalizing Exchange: Trade Liberalization and Income Convergence," Quarterly Journal of Economics, Vol. 108 (August), pp. 653-79.

Cashin, Paul, and Ratna Sahay, 1996, "Internal Migration, Center-State Grants, and Economic Growth in the States of India," IMF Staff Papers, Vol. 43 (March), pp. 123-71.

Graham, Edward M., and Erika Wada, 2001, "Foreign Direct Investment in China: Effects on Growth and Economic Performance" (unpublished; Washington: Institute for International Economics).

Husain, Aasim M., 1998, "Economic Performance and Business Cycles in China's Provinces and Regions," in People's Republic of China: Selected Issues (Washington: International Monetary Fund).

Khan, Mohsin S., 1987, "Macroeconomic Adjustment in Developing Countries: A Policy Perspective," World Bank Research Observer, Vol. 2, pp. 23-42.

Khan, Mohsin S., and Manmohan Kumar, 1997, "Public and Private Investment and the Growth Process in Developing Countries," Oxford Bulletin of Economics and Statistics, Vol. 59, pp. 69-88.

Jian, Tianlun, Jeffrey D. Sachs, and Andrew M. Warner, 1996, "Trends in Regional Inequality in China," NBER Working Paper 5412 (Cambridge, Massachusetts: National Bureau of Economic Research).

Jin, Hehui, Yingi Qian, and Barry R. Weingast, 1999, "Regional Decentralization and Fiscal Incentives: Federalism, Chinese Style" (unpublished; Stanford, California: Stanford University).

Lardy, Nicholas, 1998, China's Unfinished Economic Revolution (Washington: The Brookings Institution).

Mankiw, N. Gregory, David Romer, and David N. Weil, 1992, "A Contribution to the Empirics of Economic Growth,” Quarterly Journal of Economics, Vol. 107 (May), pp. 407-37.

People's Bank of China, various issues, Almanac of China's Finance and Banking (Beijing: China Financial Publishing House).

Qian, Yingyi, 1999, “The Institutional Foundations of China's Market Transition,” paper prepared for the Annual World Bank Conference on Development Economics, Washington DC, April 28-30.

Quah, Danny, 1997, "Empirics for Growth and Distribution: Polarization, Stratification, and Convergence Clubs," Journal of Economic Growth, Vol. 95 (December), pp. 27-59.

Solow, Robert M., 1956, "A Contribution to the Theory of Economic Growth," Quarterly Journal of Economics, Vol. 70, pp. 65-94. 


\section{Anuradha Dayal-Gulati and Aasim M. Husa in}

State Statistical Bureau, 1996, The Gross Domestic Product of China, 1952-95 (Beijing: China Statistical Publishing House).

, various issues, China Statistical Yearbook (Beijing: China Statistical Publishing House).

Swan, Trevor W., 1956, "Economic Growth and Capital Accumulation," Economic Record, Vol. 32, pp. 334-61.

Tseng, Wanda, Hoe Ee Khor, Kalpana Kochhar, Dubravko Mihaljek, and David Burton, 1994, Economic Reform in China: A New Phase, IMF Occasional Paper 114 (Washington: International Monetary Fund).

Wei, Shang-Jin, and Yi Wu, 2001, "Globalization and Inequality: Evidence from Within China" (unpublished; Washington: International Monetary Fund).

World Bank, 1994, "China: Budgetary Policy and Intergovernmental Fiscal Relations" (Washington: World Bank).

, 1997, "Income Distribution in China," China and Mongolia Department (Washington: World Bank), June.

Zhao, Rui, 1998, “Capital Mobility and Regional Integration: China 1978-95” (unpublished; Washington: International Monetary Fund). 